\title{
Re-integrating Design Education: Lessons from History
}

Peter A. Hall

Central Saint Martins, University of the Arts London peter@peterahall.com

\begin{abstract}
Throughout its short history, formal design education has struggled to find a balance between imparting technical skills and fostering bigger picture, critical and conceptual thinking; and also between notions of passive and active learning. As educators become ever cognizant of a future marked by environmental crisis and accompanying complex problems of population flux, civil unrest, pollution and waste, achieving a balance between "know how" and meta-level thinking has become more pressing. The premise of this paper is that a $21^{\text {st }}$ Century design education can further this goal by confronting the productivist entanglements of its past. It will argue that the lessons of its turbulent relationship with industry provide the seeds for an approach to learning that is better integrated with industry and society than conventional hypothetical studio assignments allow.
\end{abstract}

https://www.conftool.pro/drs2016.

Keywords: education; reform; futuring; interdisciplinarity 


\section{Introduction}

The instigators and reformers of formal design education have, throughout its short history, invariably wrought their strategies from a vision-utopian or dystopian-of the future. This paper unabashedly perpetuates this practice by identifying where the threads of past reforms might hold clues for the future of design education in an uncertain future of unprecedented degrees of biophysical change and concomitant societal change. Rather than paint a picture of the history design education as the gradual establishment of a bona fide discipline within academe, the goal here is to tease out the ways in which design education has modelled itself based on its perceived relation with the future of industry and society. In doing so, an argument will be made for an outward-facing $21^{\text {st }}$ Century design education that is simultaneously engaged with industry and society but disentangled from a productivist ethos and a consumerist model of learning, and one which favours holistic, interdisciplinary and design-thinking based approaches to responding to complex problems.

\section{Foundations of an Integrated Education}

As is well documented, formal design education emerged in the UK in the wake of the industrial revolution as part of a reform directed at what were considered poor quality machine-made artefacts. Since the teaching of design skills seemed to require a special, hands-on kind of approach different from, say, the learning of history or maths, various pedagogues endeavoured to rethink the common "learning by rote" approach, or learning about without learning how. This rethinking eventuated in apprenticeship models that were fuelled by turn-of-the- $20^{\text {th }}$ Century zeal for the reform of society. The Central School of Arts and Crafts opened in London in 1896, for example, as the result of a long-standing discussion about the poor standard of British manufacture and how industrialization had brought the decline of creativity and artisanship. The reference point was the Great Exhibition held at the Crystal Palace in 1851, which was regarded as a showcase for goods made around the world, and the poor quality of the British ones. Machine-made ornamentation applied to mass-produced objects was, according to a British government inquiry "degraded" (Crouch, 1999, p.23-4). Among the critics of the loss of hand skills and craftsmanship were the textile designer and socialist William Morris and the critic, painter and philanthropist John Ruskin, who argued that materials have an intrinsic quality that should not be transgressed: "your art is base if it does not bring out the distinctive qualities of that material" (Crouch, 1999, p.24). 
The Marxist-Romanticist zeitgeist around the Central School's founding is apparent in both the advocacy of individual expression through craftsmanship and in the productivism present in much $19^{\text {th }}$ century social, political and economic thought (Campbell, 2005, p.13): increased material production was an explicit goal of Karl Marx and John Stuart Mill (Craig, 2006, p.5). In the $21^{\text {st }}$ Century, as design education confronts its own legacy in the form of the environmental damage and accompanying problems associated with this productivist "bias" (Campbell, 2005, p.13), University and College programs are increasingly turning away from design as the production of goods and manufacture of consumer desire toward more holistic, interdisciplinary and design-thinking based approaches to responding to today's complex problems. Yet the challenge achieving this manoeuvre is that it can deprive design graduates of the very outcome for which they chose to study design in the first place: techne, or the skill of making.

In a 1993 paper, Clive Dilnot argued that questions of the evaluation of education "cannot be understood without an explicit or implicit model of design-society relations coming into play" (Dilnot, 1993, p.139). The suggestion in this paper is that such a model can be furthered not by isolating or hothousing design activity in educational institutions but by turning design education inside-out so that all teaching and learning activity relates to the full relational complexity of real world design problems. A pair of "deschooling" strategies could help achieve this reorientation: Better identifying the design profession's complicity in perpetuating an ecologically damaging way of being; and better recognition of everyday design and design thinking within organisations. But in addition, design education has much to gain from exploiting its ill-defined, itinerant status in the academy, as a subset of art, engineering, architecture, information technology or as a truly cross-disciplinary activity. To better exploit this position, an emphasis on design-in-society must replace the current curricula emphasis on hypothetical and formal design problems; and the educational institution should function to provide a preparation and reflection space for tackling wicked problems collaboration with industry, and society. 
The matter of the institution's relationship with industry and society is absolutely central to the history and future of design education; rather than aim to eject productivism from this history, it is helpful to learn from how the past has shaped present pedagogies. For instance, one outcome of the hybridization of expression and mechanical production in the Arts and Crafts education was, in places, a progressive trans-disciplinary pedagogy based on the apprenticeship model. The founder of the Central school was the architect William Lethaby, who, with the support of William Morris and others, advocated a direct handling of tools in the classroom, and dissolving the barriers between the designer (then perceived as an abstract, intellectual calling) and the craftsman or artisan (then seen as a baser calling) (Gronberg, 1984, p.18). This approach bears a relation to what we would consider today a "thinking-through-making" and "mimetic learning" (Billett, 2015) pedagogy. The predominant $19^{\text {th }}$ Century method of teaching art teachers involved copying from historical ornament, progressing painstakingly from line to geometrical form, which Morris and Ruskin felt stifled creativity. It was workers, not art teachers, they argued, who most needed training and education. Lethaby likened the dominant theoretical approach to art and design education as being like trying to learn to swim in a thousand lessons without ever getting in the water. He dispensed with paper qualifications and examinations and appointed staff who were specialist practitioners in the daytime, who taught at the school only after their main jobs were finished. Students had access to workshops in the day, and were encouraged to specialize in a particular handicraft while exploring the links between crafts: "you must go upstairs and see how stained glass windows are made and books are bound and gilding done." (Gronberg, 1984, p.18). 
The fairly simple principle, that problem-solving in one medium might be informed by problem-solving in another, has a direct correlation in the digital era, as forwarded by advocates of learning through play, in both analogue and digital media. Among his 36 learning principles of videogames, James Paul Gee includes the "transfer principle" whereby skills and strategies developed in one game are applied to solve problems in another, and by extension, to problems outside of a game format - what Gee refers to as "far transfer" (Gee, $2003,211)$. In a holistic model of design education, the importance of the transfer principle cannot be underestimated, as it liberates a practitioner skilled in a particular disciplinary area from a perceived obligation to solve a design brief as given. A designer with know-how beyond her specialism is thus able to solve the given problem by recommending expertise beyond her own. This becomes less a call for design polymaths than for adepts with disciplinary skills supported by what Gee calls metalevel thinking skills -- "active and critical thinking about the relationships of the semiotic domain being learned to other semiotic domains" (Gee, 2003, 207). A solution to a graphic user interface problem facing a Government retirement website under increased demand, for example, might be reformulated as a larger problem of rethinking the entire "user experience" from website to service centres. Conversely, a design brief to re-style a consumer hardware tool might be revised as an opportunity to establish a tool rental service, thus removing the need for disposable or barely-used tools altogether. Such scenarios were explored by Ezio Manzini's "sustainable everyday" project (Manzini \& Jegou, 2004). 


\section{Realigning Early Modernist Education}

If the Central School was an educational experiment drawn from a Romantic-Socialist vision of the future, subsequent institutions continued this experiment with the zeal of Modernist productivism. One of the many visitors impressed by the Central School was Hermann Muthesius, who went on to found the Deutscher Werkbund in Germany in 1907, an organisation dedicated to "the ennoblement of handiwork through the union of art, industry and handcraft" (Forgacs 1995, p.6). Its goal was to bring representatives of art, industry, crafts and trades to raise the quality of work which they felt was threatened by mechanisation. Walter Gropius, whose model factory was featured in Muthesius's Werkbund Exhibition in 1914 in Cologne, went on to found the Bauhaus in 1918 with a rhetoric that seemed to explicitly address Marx's dystopia of the alienated factory worker, disconnected from the products of his or her labour and "depressed spiritually and physically to the condition of a machine" (Marx, 1844, p.4). Gropius advocated a pedagogy around the "unified collective work, which conceives the creative process of design as an indivisible whole" (Wingler 1978, p.51); in place of the divided labour of the factory, where unskilled workers performed single or limited tasks, eliminating the long training period required to train craftsmen, Gropius advocated programs integrated with industry and society. He envisioned the well-trained artist having a factory at his disposal, creating new forms.

One problem with Gropius's vision is that it led not to the takeover of factories by artists, but to the supply of new forms to industry; the school was set up to counter and check the trends toward productivism, but under pressure to integrate in the dominant economic order, ended up feeding it. Among the critiques of the Bauhaus is Tony Fry's claim, drawing from Jean Baudrillard, that the school's bias towards art rather than industry mean that industrial products were reduced to mimic an "industrial look". Since Bauhaus "objects, images, rhetoric, projects, personalities all existed as published representations" (Fry 1999, p.158) the school provided the means for its own dissemination and historicisation, regardless of actual produced output (of which there was famously little). Hence Baudrillard's audacious claim that the Bauhaus marks the dawning of the object that only fully exists once it gains a sign function that transcends and directs its use function (Fry 1999, p.158): Before the Bauhaus "there were no objects" (Baudrillard, 1981, p.185). Fry adds that the Bauhaus "sought to force the future into its form. There was a fundamental failure inscribed in this idealism - unwittingly its zeitgeist ... helped expand the unsustainable" (Fry, 1999, p.154). 
Rather than unceremoniously throwing out the early Modernist experiment from the canon of design education history, a case can be made in the $21^{\text {st }}$ Century for realignment of emphasis. If productivism and the political economy of the sign have propelled human civilisation towards its own destruction, the prospect of an overpopulated, resourcedeprived future should also potentially inspire a re-evaluation of key historical moments. A contrasting journey to the Bauhaus's gradual commodification was taken in Russia by the VKhUTEMAS school, founded in 1920 by a state decree signed by Lenin, to offer, "in the spirit of freedom, an extraordinarily flexible, open and experimental course of studies" (Forgács, 1995, p.186). Students and staff eschewed an education that "nurtured personal vanities" in favour of collectivism projected in a formal language of pure colours and intersecting straight lines. A curriculum influenced by Constructivism and taught by luminaries including Alexander Rodchenko, prioritized collaboration with industrial production: students progressed from colour to graphic to mass and space construction. At the Bauhaus, industrial resources were readily available, but VKhUTEMAS staff were required to perpetually improvise with limited available resources. Rodchenko was head of the metal workshop but due to lack of metal attempted to design prefabricated buildings using standardized wooden elements. Given the shortage of apartments in Russia, where families were squeezed into single rooms, assignments were dictated by "dire necessity": "tables that a single turn could change into a seat or a workbench, or chairs that could convert into beds" (Forgács, 1995, p.191).

If the Bauhaus set in motion a contemporary design education based on the object as sign and an increasingly codified, formalist education (see Grady 2006), the legacy of the VKhUTEMAS is arguably yet to be felt. It has more resonance today, as we face the tasks of designing tiny houses and smaller more flexible residences for ever-increasing human populations. Vladimir Tatlin's rallying cry might indeed serve a contemporary design-build or service design assessment: "We need objects that are as simple and primitive as our way of life" (Forgács, 1995, p.191). 


\section{Lessons from Sixties Radicalism}

The contemporary landscape of design education presents a bewildering array of models, that might be arranged on a spectrum, from the "vocational" programme focused mainly on providing job-ready technical skills and know-how, to the critical-theoretical programme, focused on the critique of contemporary and historical design practices, and advocacy of new approaches. In between these poles are a number of influential models, such as the "citizen architect" approach of the Rural Studio at Auburn University, which has introduced multiyear design/build engagements with deprived communities in rural areas of Alabama, including a $\$ 20,000$ house project: Student teams design and build one-bedroom homes within a small budget, based on the maximum federal housing assistance loan amount available to very low income home owners in Hale County, Alabama (Hinson, 2007, pp.24-6). The inherent idea is that in the experiential process of learning on-the-job "know how" the student also grasps a practical and theoretical understanding of ethics, social justice and injustice. This has gained traction in other design disciplines in educational programmes in recent years; it also underlies the research question behind the case study that will be discussed in closing: How can learning technical and practical skills be better combined with theoretical and meta-level reasoning skills via a work-integrated learning programme? (The Australian term "work-integrated learning" is preferred here to the UK term "work-based learning" because the latter tends to imply that the learning happens in the workplace. While the scenario of a solo student on secondment in a professional workplace is also common in Australia, the term "integrated" allows for an alternative model: the "live" project is imported into the classroom, arguably more in the spirit of Lethaby's Central School model, with its teachers imported from industry.)

Before discussion of the case study, however, it is helpful to better develop the overview of historical design education reforms and their larger contexts begun at the outset of this paper. Of particular interest is the role of student activism in triggering reforms; this might be seen as a counter to the autopoietic drive of institutions and professions to sustain themselves. In the philosophy of Niklas Luhmann, this drive is commonly in spite of the environmental complexity (and the ecological problems) in which these institutions exist: "The primary goal of autopoietic systems is the continuation of autopoiesis without any concern for the environment" (Luhmann, 1989, p.12). 
Student activism provides a reasonably reliable indicator of situations in which institutions (or systems) have become impervious to the currents of change underway in the larger environment. When the architect Mies van der Rohe was appointed director of the Bauhaus in 1930, students suspected reactionary tendencies and demanded that he exhibit his work "to enable them to decide whether or not he was qualified to direct the Bauhaus. (Mies called in the police, and several students were expelled from the school) (Forgács, 1995, p.194). With its founding in 1920, the VKhUTEMAS reflected the demands of an art school student conference in 1918, where students argued for an arts education free of "petty egotism" and free of "diplomas, ranks, awards and privileges". Fifty years later, students at the Hornsey College of Art in London staged a sit-in, calling for a major review of an anachronistic art curriculum, and critiquing the education system at the time in a document published as The Hornsey Project. Students, no doubt inspired by concurrent events in Paris in May 1968, called for the abolition of entrance requirements, exams and student control of whatever took their place.

A context for the 1968 events is provided, post-event, by Ivan Illich's radical critique of institutionalized education, in which he argued that true public education requires the "deschooling of society". Institutionalized schooling, argued Illich, has resulted in pupils confusing teaching with learning, grade advancement with education, a diploma with competence and fluency with the ability to say something new (Illich, 1971, p.3). In place of institutionalized education that seeks ultimately to maintain itself and the status quo, Illich argued for a self-directed, incidental and informal education, supported by social relations: "educational webs which heighten the opportunity for each one to transform each moment of his living into one of learning, sharing, and caring" (Illich, 1971, p.2).

Like Illich, Fry argues that we are taught ways of knowing and acting in professional and nonprofessional lives that replicate "specific forms of the unsustainable." (Fry 2009, p.174). He makes a case for a broader sense of education, beginning with "a reflective interrogation of one's knowledge, to begin to identify what one has formally and informally learnt and what in hindsight, can be seen as "an induction into error"”" (Fry, 2011, p.214). 
The implication that education is bigger, longer, and more important than what happens in classes is echoed in the writings of the designer and anarchist Norman Potter. Together with a group of architects, designers, a philosopher and English language specialist, Potter set up the Construction School in Bristol in 1964, which drew in part from Lethaby's approach to an artisan, workshop-orientated design education. One of the School's goals was to set up a three-year design course without specialisation, leading to various areas of design including architecture (a degree in which was completed in an additional two years). Students were introduced to an intellectually demanding first year concerned with problem-solving and communication; the second year opened out into workshop practice and technical studies in wood, metals and plastics; and the third year linked disciplines in exhibition design. The school achieved a noted level of critical discussion, strong student-centred learning ethos and a high standard of work.

Potter, who started writing What is a Designer after the revolts of 1968, when he joined the students at Hornsey college of Art, argues that the beginner can draw confidence from the same source as a seasoned designer once it is realised that the foundations of judgement in design are "rooted in ordinary life and in human concerns not in some quack professionalism" (Potter, 2002, p.95).

This brings us to the identity crisis that perhaps prohibits a full confrontation within design education. If design judgement is rooted in ordinary life and human concerns, then what is the purpose of a formal design education? Illich, Fry and Potter would argue that most of the time it is there to uphold the status quo and control who gets to call themselves a professional designer. A profession, according to Potter, can become a "self-protection society with a very short term view of the priorities for professional competence" (Potter, 2002, p.22). At the same time, both Fry and Potter clearly see another more subversive or empowering role for design education. 
The question is quite dramatically thrashed out in the spaces of learning we inhabit. In the workshops and labs, under close supervision, students learn by watching and doing; in tutorials and seminars, students learn by discussing, presenting and debating; in lectures, students learn by watching and listening. But this is not a neat segregation of spaces and methods, nor is it free of controversy. According to Jacques Rancière, the theatre and the classroom are alike in that both seek to dissolve the very thing on which they are premised, the distance between the stage and the audience, between the "expert" and the student (Rancière, 2014, p.8). On the stage is the teacher whose aim is to dissolve the gap between his "expert" knowledge and the students' ignorance. This distance must be sequentially dissolved and reconstructed; because if the students knew as much as their teacher, then what is the teacher doing on the stage? The teacher achieves this by remaining one step ahead of the students. Unless, as Rancière argues, we follow the lesson of the ignorant schoolmaster, which argues for the equality of intelligence, that all learning is achieved by individuals comparing what is in front of them (what they don't know) with what they do know. In a direct challenge to the theories of the Frankfurt School, which tended to paint a more pessimistic picture of the brainwashed masses, Rancière draws from the ideas of Joseph Jacotot, a French schoolteacher who developed during the Restoration a method for showing illiterate parents how they could teach their children how to read (Rancière, 1987 p.vii). The ignorant schoolteacher has "uncoupled his mastery from his knowledge. He does not teach his pupils his knowledge but orders them to venture into the forest of things and signs, to say what they have seen and what they think of what they have seen, to verify it and have it verified" (Rancière, 2014, p.17).

This suggests that schooling needs to achieve a blend of modes to facilitate this process of saying what has been seen and what one thinks of it, verifying it and having it verified: I show you a thing, an idea or concept in the lecture; you go to the tutorial and say what you have seen, compare it to what you know, and say what you think you have learned. This is verified in class or in a paper, a sketch, model, prototype, schematic, map or final rendering. 
It was suggested earlier that the late $19^{\text {th }}$ and early $20^{\text {th }}$ Century versions of visions of design education prioritized artisanship and its integration in society for the improvement of living conditions, yet slipped so easily into feeding new forms, fashions and obsolescence to a consumer culture whose doppelganger was environmental destruction. In the $21^{\text {st }}$ Century, we know that design problems cannot simply be solved with a neat logo, a road tunnel, waterfront regeneration or a shopping mall. Design problems are complex and require an understanding of relational systems, of the potential impacts of bringing a design into the world. Understanding dynamic systems and our role in those systems is the first part of changing our impact on those systems. This calls for an ability to navigate complex problems and research them. As John Seely Brown argued in a PBS documentary on $21^{\text {st }}$ Century learning, "In a world of rapid change, the need to memorize something is a 20th century skill. The need to navigate in a buzz of confusion and to figure out how to trust the information that you find, if you can feel confident doing that, the world is yours" (PBS 2013).

But at the same time, for a design student to become a professional capable of contributing to complex problem tackling requires a recognisable skillset. The importance of strong craft, visualization and technical skills, it would seem, is that they give the designer an opportunity to exercise organisational, participatory planning, brainstorming, stage setting -- in short, design thinking -- skills. This, then, is one reason why it becomes necessary to cultivate a recognisable know-how or techne; for the designer to earn a seat at the negotiating table. 


\section{Case Study}

A closing case study aims to address the question raised earlier, how can learning technical and practical skills be better combined with theoretical and meta-level reasoning skills via a work-integrated learning programme?

The LiveSpace design studio, established by the author and colleagues at Queensland College of Art in 2013, creates a simulation of a professional studio in the classroom, supporting work-integrated learning on real-world projects scaffolded by higher order thinking. This aims at creating a form of "mimetic" learning, which can potentially also present an opportunity to "transform what constitutes...occupational practice." (Billett, 2014 , p.100). Billett suggests that when individuals engage in work activities for specific purposes, they are "actively remaking that occupational practice, thereby realising its continuity". This act of remaking can either perpetuate existing practices in changing circumstances, or it can "contribute to the transformation of what constitutes that occupational practice" (Billett, 2014, p.13). Project-based learning at LiveSpace supports the development of practical design-build and prototyping skills along with time management, client communication and team-based learning. A larger curricular context emphasises futural, participatory and sustainable design practices.

LiveSpace projects to date have explored a number of critical issues relating to environmental crisis. For example, a project with a local museum established an interactive exhibition aimed at introducing high school children to the problem of electronic waste. Another current project with a local annual festival explores low impact fixtures and street furniture that can be easily moved and disassembled, in line with concurrent learning around the increasing importance of moveable architecture amid extreme weather events and itinerant refugee populations. Finally, a project with a counselling service and University based suicide prevention clinic developed scenarios and personas for testing the viability of an app-based software programme for self-monitoring mood and anxiety. All three projects purposely move the design project beyond traditional client-designer relations where the brief arrives "pre-cooked". Instead they support "redirecting" (Fry, 2007) the client brief so that meta-level questions can be used to reframe the given problem. In the scaffolded environment of LiveSpace, students are arguably able to test redirective strategies in authentic scenarios, contributing to the remaking of practice. 
Mimetic learning describes how, prior to industrial and institutionalized education, people learned occupational skills in the workplace. "Rather than novices being taught or even guided, the key responsibility was for them to actively learn the occupation... There was evidence of arrangements for novices to engage in work activities incrementally and progressively in developing the capacities required to practice the particular occupation" (Billett, 2014, p.vii). One challenge with work-integrated learning or placements today, however, is familiar to any design student who has been told by his or her employer to "forget everything they've learned at University". This is particularly problematic when the program of study purposely sets out to redefine and reinvent the vocation for which the student is being prepared.

Yet as Billett argues, in the history of mimetic learning it is inconceivable that the apprentice would not, in some way, remake the practice while learning it. This idea echoes Rancière's case for the emancipated spectator and the student of the ignorant schoolmaster, the student who learns by comparing and verifying what she has seen. The anthropologist Tim Ingold argues that skills are not in fact passed on by learning rules or pre-formed representations, but by "placing novices in situations where they engage in active processes of perception, action and attention; this remaking takes the form of guided re-discovery" which is analogous to Billett's concept of remaking and potential transforming. "That remaking can comprise the mere rehearsal and remaking of what has gone on before, albeit in changing circumstances, or it can contribute to the transformation of what constitutes that occupational practice" (Billett, 2014, p.13).

To support such a transformation, argues Billett, an educational program needs to prepare students for the work-integrated learning experience, (including the kinds of "forget everything you've learned" contestations) and also to provide opportunities for students to compare and contrast their work experiences during and after the event. This, as Rancière noted, is a part of learning, to say what you have seen and what you think of what you have seen, to verify it and have it verified.

In many ways, this account of reflective learning provides for the missing portion of the idealistic educational reforms discussed earlier in the paper; because it allows for the individual to reinterpret knowledge - whether it is the knowledge learned on the job, in the lecture theatre or from the designed artefacts that designers have sent out into the world. Rancière, Ingold and Billett, in this sense, are providing a better account of how design works in the world - rather than how it works on the drawing board or in the computer.

\section{References}

\section{References}

Baudrillard, J. \& Levin, C. (1981). Design and environment or how political economy escalates into cyberblitz. In For a Critique of the Political Economy of the Sign, St. Louis, Missouri: Telos Press. 
Billett, S. (2014). Mimetic learning at work: Learning in the circumstances of practice. Cham, Switzerland: Springer.

Campbell, C. (2005). The romantic ethic and the spirit of modern consumerism. Oxford, UK: Basil Blackwell.

Craig, D. (2006). John Ruskin and the ethics of consumption. Charlottesville and London: University of Virginia Press.

Crouch, C. (1999). Modernism in art, design and architecture. London:Palgrave Macmillan 1999.

Dilnot, C. (1982). Design as a socially significant activity. Design Studies, 3 (3) 139-146.

Forgács É \& Bátki, J. (1995). The Bauhaus idea and Bauhaus politics. Budapest, London, New York: Central European University Press.

Fry, T. (1999). A new design philosophy: an introduction to defuturing. Sydney: UNSW Press.

Fry, T. (2007). Redirective practice: An elaboration. Design Philosophy Papers 5(1) 5-20.

Fry, T. (2011). Design as politics. Oxford; New York: Berg.

Gee, J. (2003). What video games have to teach us about learning and literacy. New

York: Palgrave/Macmillan.

Grady, M. (2006). Art and consciousness-the pedagogy of art and transformation. Visual Arts Research 32 (1), 83-91

Gronberg, T. (1984). William Richard Lethaby and the Central School of Arts and Crafts. WR Lethaby 18571931: Architecture Design and Education. Edited by Sylvia Backemeyer and Theresa Gronberg. London: Lund Humphries

Hinson, D. (2007 ). Design as research: learning from doing in the design-build studio." Journal of Architectural Education, 23-26

Illich, I. (1971). Deschooling society. Harmondsworth: Penguin.

Luhmann, N. (1989). Ecological communication. Chicago: University of Chicago Press.

Manzini, E \& Jegou, F. (2003). Sustainable Everyday: Scenarios of Everyday Life. Milan: Edizione Ambiente.

Marx, K. (1844). Economic and philosophic manuscripts of 1844. Web, accessed 15 November 2015. https://www.marxists.org/archive/marx/works/1844/manuscripts/preface.htm

PBS. (2013). "Digital media: New learners of the $21^{\text {st }}$ century." Tuesday September 3, 2013. Web https://vimeo.com/20018135. Accessed 15 November 2015.

Potter, N. (2002). What is a designer? London: Hyphen Press.

Rancière, J. (1987). The ignorant schoolmaster. Stanford, CA: Stanford University Press.

Rancière, J. (2014).The emancipated spectator. London and New York: Verso Books.

Wingler, H. (1978). The Bauhaus. Cambridge Mass and London, England: The MIT Press. 
PETER A. HALL [Re-integrating Design Education]

Acknowledgements: The case study in this paper is adapted from research with colleagues at Griffith University Queensland College of Art

About the Authors:

Peter A. Hall is a design writer and course leader of the BA Graphic Design at Central Saint Martins, University of the Arts London. He was previously head of the Bachelor of Design Futures at Queensland College of Art, Australia. 